\title{
Dyr med demens?
}

\author{
Er demens forbeholdt mennesker eller kan gnagere også rammes? Vi trenger dyreforsøk for å lære prinsip- \\ pene om hvordan hjernen fungerer, men vi må ikke glemme at slike forsøk bygger på dyremodeller. Demens \\ slik det er definert i dagens medisinske litteratur, er fremdeles unikt for mennesket.
}

En forsker som studerer atferden til hunder, aper, rotter, snegler, gullfisk eller andre dyr, kan oppdage at dyrene oppfører seg som om de er i stand til å tenke over fremtiden. Det å oppføre seg som om man har en slik evne, og det faktisk å besitte evnen er ikke det samme. Dyr klarer ikke å tenke over fremtiden slik mennesker gjør. Dette er godt poengtert i boken Hva er lykke? av Harvard-professoren Daniel Gilbert (1). Han holder fast ved prinsippet om at kun mennesker tenker over fremtiden, og det vil han gjøre inntil den dagen det blir påvist at en sjimpanse gråter ved tanken på å bli gammel alene.

\section{Uteblitte gjennombrudd}

Forskere anvender genetisk manipulerte dyr for å undersøke ulike patologiske mekanismer som forekommer ved Alzheimers sykdom og andre typer av demens. Innen nevrovitenskap er denne forskningen nødvendig og helt sentral, samtidig som den utfyller den kliniske forskningen. Utfordringen ligger ved selve formidlingen av resultatene fra dyreforsøkene. I sammendragene i flere publiserte artikler om dyreforsøk innledes det med at Alzheimers sykdom er forbundet med opphopning av amyloide plakk, tau-floker og andre endringer i hjernen (2). Få forskere understreker at Alzheimers sykdom og andre typer demens er unikt for mennesker. Å proklamere at mus med Alzheimers sykdom opplever å huske bedre etter en ny type behandling, er en uheldig formulering av følgende grunner:

- Mus kan aldri per se ha Alzheimers sykdom - Hukommelse måles veldig grovt i mus

- Det er ingen garanti for at behandlingen som ga resultater hos musene, vil fungere hos mennesker

Det vil ikke si at resultatene er uviktige for å forstå deler av Alzheimers sykdom, men det er bedre at de blir videreformidlet på en sober måte og ikke overtolket av forskerne. Fallhøyden ved overdreven bruk av antropomorfisme kan være stor, og forskere overvurderer i blant betydningen av dyreforsøk innen demensforskning (3). Demens er fortsatt en klinisk diagnose som ofte er krevende å stille, til tross for nye diagnostiske metoder og teknologiske hjelpemidler (4). Det er bred enighet om at dyremodeller har gitt verdifull informasjon om demens de siste 20 årene, spesielt kunnskap om arvelige varianter av Alzheimers sykdom, selv om de store gjennombruddene foreløpig har latt vente på seg (5). At den terapeutiske betydningen har uteblitt hos mennesker, kan skyldes at transgene mus ikke er representative for sporadiske tilfeller av demens (6).

\section{Hvilken dyremodell er best?}

Basalforskere ønsker å ta høyde for at demens forekommer hos eldre mennesker ofte uten genetisk disposisjon, og har derfor studert hjernene til aldrende marsvin. Ved å påføre marsvin lett grad av hodetraume kan man også angivelig undersøke om hjerneskade er en risikofaktor for Alzheimers sykdom (7). Har marsvin mer egnede hjerner enn mus som modell for de patologiske endringene som oppstår ved Alzheimers sykdom? Siden demens innebærer sammensatte endringer i hjernen, er det vanskelig å si hva som konstituerer en optimal dyremodell (8). Uansett dyremodell som velges, er det viktig at forfatterne opplyser om hvilke begrensninger modellen har når funnene skal publiseres og overføres til mennesker (9). Når for eksempel tittelen på en studie sier at nye hjerneceller er blitt dannet $i$ en musemodell med Alzheimers sykdom, bør også teksten, inkludert de siste oppsummerende setningene, være stringente og med presisering om at funnene gjelder mus og ikke mennesker (10).

\section{Glemske og språkfattige dyr}

Når vi tenker over fortiden og fremtiden, brukes episodisk hukommelse. Denne svikter hos en person med Alzheimers sykdom. Ingen dyr er i stand til å foreta en mental tidsreise, men ved å bruke en utvidet definisjon kan forskere si at dyr har en tilnærmet lik menneskelig episodisk hukommelse (11). Har virkelig gnagere en evne til å erindre som samsvarer menneskets, eller er det kun mer fordelaktig for forskere innen nevrovitenskapen å anta dette?

En annen løsning på problemet er å tilskrive dyr en «episodiskliknende» hukommelse, at hukommelsen likner, men ikke er identisk med menneskets (12). Det er ikke hukommelse alene som svikter ved demens. Klarer dyremodeller også å forklare atferdsforandringer? Svaret ligger i å innføre begreper som «angstliknende» atferd i dyremodeller med Alzheimers sykdom (13). Dyremodeller kommer dessverre uansett til kort. Hvordan skal det å huske fakta eller ord og begreper (semantisk hukommelse) måles hos dyr? Eller hva med redusert innsikt, dårlig dømmekraft, usikkerhet, mistenksomhet, sosial isolasjon, mangel på leselyst og tap av hobby, som kun er noen symptomer på demens? Er disse symptomene mindre viktig å forske på eller bare mindre målbare i dyremodeller? Forskere bør heller ikke overse den mest distinkte kognitive evnen mennesker har, nemlig språket.

For å parafrasere Daniel Gilbert: Inntil dyr utvikler et mer rikt språk er det kun mennesker som kan rammes av demens (1). Dyr kan i beste fall ha demensliknende symptomer. Så la oss være åpne om begrensningene ved dyremodeller.

\section{Tor Atle Rosness}

tor.rosness@legeforeningen.no

Tor Atle Rosness (f. 1976) er postdoktor ved Avdeling for samfunnsmedisin, Institutt for helse og samfunn, Universitetet i Oslo, og medisinsk redaktør i Tidsskriftet. Forfatter har fylt ut ICMJE-skjemaet og oppgir ingen interessekonflikter.

\section{Litteratur}

1. Gilbert D. Hva er lykke? Oslo: Monstro bok, 2007

2. Sipos E, Kurunczi A, Kasza A et al. Beta-amyloid pathology in the entorhinal cortex of rats induces memory deficits: implications for Alzheimer's disease. Neuroscience 2007; 147: 28-36.

3. Zahs KR, Ashe KH. 'Too much good news' - are Alzheimer mouse models trying to tell us how to prevent, not cure, Alzheimer's disease? Trends Neurosci 2010; 33: $381-9$.

4. Aarsland D, Rongve A, Fladby T et al. Alzheimers sykdom og genetikk. Tidsskr Nor Legeforen 2013; 133: $1449-52$.

5. Epis R, Gardoni F, Marcello E et al. Searching for new animal models of Alzheimer's disease. Eur J Pharmacol 2010; 626: 57-63

6. Lecanu L, Papadopoulos V. Modeling Alzheimer's disease with non-transgenic rat models. Alzheimers Res Ther 2013; 5: 17

7. Bates K, Vink R, Martins R et al. Aging, cortical injury and Alzheimer's disease-like pathology in the guinea pig brain. Neurobiol Aging 2014; 35: 1345-51.

8. Chin J. Selecting a mouse model of Alzheimer's disease. Methods Mol Biol 2011; 670: 169-89.

9. Dodart JC, Mathis C, Bales KR et al. Does my mouse have Alzheimer's disease? Genes Brain Behav 2002; 1: 142-55.

10. Rodríguez JJ, Jones VC, Tabuchi M et al. Impaired adult neurogenesis in the dentate gyrus of a triple transgenic mouse model of Alzheimer's disease. PLOS ONE 2008; 3: e2935.

11. Ferbinteanu J, Kennedy PJ, Shapiro ML. Episodic memory-from brain to mind. Hippocampus 2006; 16: $691-703$

12. Crystal JD. Elements of episodic-like memory in animal models. Behav Processes 2009; 80 : 269-77.

13. Lok K, Zhao H, Zhang $C$ et al. Effects of acceler ated senescence on learning and memory, locomotion and anxiety-like behavior in APP/PS1 mouse model of Alzheimer's disease. J Neurol Sci 2013; 335: 145-54

Mottatt 21.3. 2014, første revisjon innsendt 17.4. 2014, godkjent 15.5. 2014. Forfatteren er redaktør i Tidsskriftet. Manuskriptet er derfor behandlet eksternt av en uavhengig redaktør, Magne Nylenna.

Publisert først på nett. 